\title{
Continuous infusion of rocuronium in a paediatric intensive care unit
}

Purpose: To evaluate prospectively the efficacy and dose requirements of rocuronium administered by continuous infusion for neuromuscular blockade in a paediatric ICU population.

Methods: Neuromuscular function was monitored by train-offour (TOF) stimulation of the ulnar or peroneal nerve. Rocuronium was administered as a bolus dose $\left(0.6 \mathrm{mg} \cdot \mathrm{kg}^{-1}\right)$ followed by a continuous infusion starting at $0.6 \mathrm{mg} \cdot \mathrm{kg}^{-1} \cdot \mathrm{hr}^{-1}$. The infusion was increased or decreased by $0.1 \mathrm{mg} \cdot \mathrm{kg}^{-1} \cdot \mathrm{hr}^{-1}$ to maintain one visible twitch of the TOF. All patients also received a benzodiazepine or a barbiturate infusion.

Results: The study population included 20 patients (12 boys, eight girls) ranging in age from two months to $16 \mathrm{yr}$ and in weight from 3.6 to $64 \mathrm{~kg}$. The duration of the rocuronium infusion varied from 26 to $172 \mathrm{hr}$ for a total of $1492 \mathrm{hr}$ in the 20 patients. The rocuronium infusion requirements for day 1 varied from 0.3 to $0.8 \mathrm{mg} \cdot \mathrm{kg}^{-1} \cdot \mathrm{hr}^{-1}\left(0.76 \pm 0.3 \mathrm{mg} \cdot \mathrm{kg}^{-1} \cdot \mathrm{hr}^{-1}\right)$. When considering all patients and all patient days, the rocuronium infusion rate required to maintain one twitch of the TOF varied from 0.3 to $2.2 \mathrm{mg} \cdot \mathrm{kg}^{-1} \cdot \mathrm{hr}^{-1}$ (mean for all patient days $\left.=0.95 \pm 0.4 \mathrm{mg} \cdot \mathrm{kg}^{-1} \cdot \mathrm{hr}^{-1}\right)$. The infusion requirements were 0.5 to $0.8 \mathrm{mg} \cdot \mathrm{kg}^{-1} \cdot \mathrm{hr}^{-1}$ in 45 of the 64 patient days (70\%) and 0.3 to $1.0 \mathrm{mg} \cdot \mathrm{kg}^{-1} \cdot \mathrm{hr}^{-1}$ in 58 of the 64 patient days (90\%). No problems with the infusion were noted.

Conclusions: Continuous infusion of rocuronium can be used to provide neuromuscular blockade in the paediatric ICU

\section{Key words}

ANAESTHESIA: paediatric;

INTENSIVE CARE: paediatric, ventilation; NEUROMUSCULAR RELAXANTS: rocuronium; NEUROMUSCULAR TRANSMISSION: stimulator, nerve.

From the Departments of Child Health and Anesthesiology, the Division of Pediatric Critical Care/Anesthesia, the University of Missouri, Columbia, Missouri.

Address correspondence to: Dr. Joseph D. Tobias, Director, Pediatric Critical Care/Anesthesia, The University of Missouri, Department of Child Health, M658 Health Sciences Center, One Hospital Drive, Columbia, Missouri 65212.

Phone: (314) 882-6544. Fax: (314) 882-2742.

Accepted for publication 17th December, 1995 patient. Due to the variability in infusion requirements, monitoring of neuromuscular function is suggested.

Objectif: Evaluer de façon prospective l'efficacité et la quantité nécessaire de rocuronium administré en perfusion continue à des enfants dans une unité de soins intensifs.

Méthodes: La fonction neuromusculaire était monitorée avec le train-de-quatre (TOF) au niveau du nerf péroné ou cubital. Le rocuronium était administré en bolus $\left(0,6 \mathrm{mg} \cdot \mathrm{kg}^{-1}\right)$ suivi par une perfusion continue initiale de $0,6 \mathrm{mg} \cdot \mathrm{kg}^{-1} \cdot \mathrm{hr}^{-1}$. La perfusion était augmentée ou diminuée de $0,1 \mathrm{mg} \cdot \mathrm{kg}^{-1} \cdot \mathrm{hr}^{-1}$ pour maintenir un twitch visible au TOF. Tous les patients ont reçu une benzodiazépine ou un barbiturique en perfusion.

Résultats: La population étudiée comprenait 20 patients (I2 garçons. huit filles) dont l'âge variait de deux mois à 16 ans et le poids de 3,6 à $64 \mathrm{~kg}$. La durée de la perfusion de rocuronium a varié entre 26 et $172^{\circ} \mathrm{h}$ pour un total de $1492 \mathrm{~h}$ pour les 20 patients. Les besoins par jour de rocuronium en perfusion ont varié de 0,3 à $0,8 \mathrm{mg} \cdot \mathrm{kg}^{-1} \cdot \mathrm{hr}^{-1}\left(0,76 \pm 0,3 \mathrm{mg} \cdot \mathrm{kg}^{-1}\right.$ $\left.\cdot h r^{-1}\right)$. Si on considère l'ensemble des patients et des jourspatients, la vitesse de perfusion du rocuronium requise pour maintenir un twitch au TOF a varié de 0,3 à $2,2 \mathrm{mg} \cdot \mathrm{kg}^{-1} \cdot \mathrm{hr}^{-1}$ (moyenne pour les jours-patients $=0,95 \pm 0,4 \mathrm{mg} \cdot \mathrm{kg}^{-1} \cdot \mathrm{hr}^{-1}$ ). Les besoins ont été de 0,5 à $0,8 \mathrm{mg} \cdot \mathrm{kg}^{-1} \cdot \mathrm{hr}^{-1}$ dans 45 des 64 jours-patients (70\%) et de 0,3 à $\mathrm{l} \mathrm{mg} \cdot \mathrm{kg}^{-1} \cdot \mathrm{hr}^{-1}$ dans 58 de 64 jours-patients (90\%). Les perfusions n'ont pas causé de difficultés.

Conclusions: Une perfusion continue peut être utilisée pour procurer la curarisation chez des enfants hospitalisés l'unité des soins intensifs. A cause de la variabilité des besoins, on suggère de monitorer la fonction neuromusculaire.

Several factors and situations may necessitate the use of neuromuscular blocking agents in the paediatric intensive care unit (PICU) patient. Suggested indications for neuromuscular blocking agents (NMBAs) include the prevention of patient-ventilator asynchrony, the facilitation of mechanical ventilation, the elimination of shivering, a reduction of peripheral oxygen utilization, control of intracranial pressure, and the facilitation of invasive or diagnostic procedures. ${ }^{1,2}$ 
For the critically ill ICU patient, continuous infusions may be chosen to maintain a stable, baseline level of blockade and thereby avoid periods of decreased blockade and the chances of excessive, perhaps harmful, patient movement. When continuous infusions are used, vecuronium remains one of the more commonly used agents because of its lack of cardiovascular effects. Other commonly used agents such as atracurium can lead to hypotension from histamine release while pancuronium and its vagolytic activity can lead to tachycardia and hypertension.

Rocuronium is a recently introduced, non-depolarizing agent, that has been reported to have a more rapid onset than other non-depolarizing agents. ${ }^{3,4}$ Like vecuronium, rocuronium in clinical doses has been shown to cause negligible histamine release and has minimal effects on cardiovascular function. ${ }^{5,6}$ While there is ample clinical experience and information concerning vecuronium infusions and dosing requirements in the ICU patient, there is no information concerning the dosing of rocuronium by continuous infusion in the PICU population. A prospective, open label evaluation was performed to determine the infusion requirements of rocuronium in a Paediatric ICU population.

\section{Methods}

The study was approved by the Institutional Review Board and the Committee for the Protection of Human Subjects of Vanderbilt University. The patient population included patients admitted to the pediatric intensive or intermediate care units in whom it was decided by the attending physician that neuromuscular blockade was indicated. All patients were sedated with a continuous infusion of either a benzodiazepine (lorazepam, midazolam) or a barbiturate (pentobarbital). In addition, an opioid infusion (morphine, fentanyl) was added for patients requiring an analgesic (i.e., postoperative patients).

The following demographic data were obtained: age, weight, sex, underlying medical problems, and concurrent medications. Patients with impairment of renal function (creatinine concentration $>1.5 \mathrm{mg} \cdot \mathrm{dL}^{-1}$ ) or hepatic function (liver enzymes, bilirubin $>$ twice normal) were excluded.

Rocuronium was administered in three situations. If no previous NMBA had been administered, a bolus of rocuronium $\left(0.6 \mathrm{mg} \cdot \mathrm{kg}^{-1}\right)$ was administered (Group 1) and the train-of-four (TOF) monitored (see below). If the patient had previously received other NMBAs, the TOF was tested. If more than the first twitch of the TOF was present (one twitch), a bolus of rocuronium $\left(0.6 \mathrm{mg} \cdot \mathrm{kg}^{-1}\right.$ ) was administered (Group 2). In Groups 1 and 2 , an infusion of rocuronium was started at 0.6 $\mathrm{mg} \cdot \mathrm{kg}^{-1} \cdot \mathrm{hr}^{-1}$ when recovery of the first twitch of the
TOF was noted. If patients had received other NMBAs and had no twitches (Group 3), a rocuronium infusion was started at $0.6 \mathrm{mg} \cdot \mathrm{kg}^{-1} \cdot \mathrm{hr}^{-1}$ when the first twitch of the TOF was observed.

A nerve stimulator (Periphral Nerve Stimulator NS252, Fisher \& Paykel, Auckland, New Zealand) was applied to either the ulnar or the peroneal nerve and a TOF was monitored every two hours once the infusion was started. Stimulation was at $50 \mathrm{~mA}$ at $2 \mathrm{~Hz}$ for two seconds. The TOF was counted by visual observation of the number of twitches. The infusion of rocuronium was increased or decreased in increments of 0.1 $\mathrm{mg} \cdot \mathrm{kg}^{-1} \cdot \mathrm{hr}^{-1}$ as needed to maintain one twitch of the TOF. In patients that required an increase in the infusion rate, an additional bolus dose (equivalent to the current hourly rate) was administered prior to increasing the infusion rate.

The rocuronium dose requirement for each day was calculated in $\mathrm{mg} \cdot \mathrm{kg}^{-1} \cdot \mathrm{hr}^{-1}$ for the $24 \mathrm{hr}$ period. Day 1 was considered to start at the time that the infusion was started and to end $24 \mathrm{hr}$ later. The number of dose changes each day was recorded. The bedside nurse noted and recorded any problems with the use of rocuronium for neuromuscular blockade. Specifically, these problems included: inadequate ability to titrate the infusion to maintain one twitch of the TOF, patient movement despite no twitches on the TOF, and excessive increases in heart rate or blood pressure. When neuromuscular blockade was no longer clinically indicated, the infusion was discontinued and the time until return of normal neuromuscular function (TOF ratio $=1.0$ and sustained tetanus to $50 \mathrm{~Hz}$ ) was noted. Sustained tetanus was administered only with appropriate sedation and analgesia.

In the patients that received rocuronium for at least three and five days, the daily infusion requirements were compared with those of day 1 using a repeated measures analysis of variance. In patients that received a bolus dose of rocuronium, the heart rate and blood pressure (systolic/diastolic) were recorded every minute for five minutes. The highest values of these variables were compared with the baseline values using a paired $t$ test. All data are presented as the mean \pm SD.

\section{Results}

The study population included 20 patients (12 boys, eight girls) ranging in age from 2 mo to $16 \mathrm{yr}(5.6 \pm 4.4$ yrs) and in weight from 3.6 to $64 \mathrm{kgs}(19.8 \pm 16.2 \mathrm{~kg})$. The duration of the rocuronium infusion varied from 26 to $172 \mathrm{hr}(74.6 \pm 41.2 \mathrm{hr})$ for a total of 1492 hours in the 20 patients. The admitting diagnosis included pulmonary parenchymal disease in 14 patients (adult respiratory distress syndrome, bronchiolitis, asthma, pneu- 
monia), airway diseases in four patients (epiglottitis, croup), and increased intracranial pressure in two patients.

Fourteen of the 20 patients received an initial bolus dose of rocuronium $\left(0.6 \mathrm{mg} \cdot \mathrm{kg}^{-1}\right)$ prior to starting the infusion. In these 14 patients, there was an increase in heart rate and blood pressure (systolic/diastolic). from baseline (Table). The maximum increase in heart rate was 24 beats $\cdot \mathrm{min}^{-1}$ while the maximum increase in systolic blood pressure was $24 \mathrm{mmHg}$. In the remaining six patients, neuromuscular blockade was initiated with another NMBA and the initial TOF demonstrated one or no twitch response. In these six patients, neuromuscular blockade was provided by starting the rocuronium infusion without a bolus. There was no difference in the infusion requirements on day 1 between the groups and therefore the data (i.e., daily infusion requirements) are considered.

The rocuronium infusion requirements for day 1 varied from 0.3 to $0.8 \mathrm{mg} \cdot \mathrm{kg}^{-1} \cdot \mathrm{hr}^{-1}\left(0.76 \pm 0.3 \mathrm{mg} \cdot \mathrm{kg}^{-1} \cdot \mathrm{hr}^{-1}\right)$. Considering all patients and all patient days, the rocuronium infusion rate required to maintain one twitch of the TOF varied from 0.3 to $2.2 \mathrm{mg} \cdot \mathrm{kg}^{-1} \cdot \mathrm{hr}^{-1}$ (mean for all patient days $=0.95 \pm 0.4 \mathrm{mg} \cdot \mathrm{kg}^{-1} \cdot \mathrm{hr}^{-1}$ ). The infusion requirements were 0.5 to $0.8 \mathrm{mg} \cdot \mathrm{kg}^{-1} \cdot \mathrm{hr}^{-1}$ in 45 of the 64 patient days (70\%) and 0.3 to $1.0 \mathrm{mg} \cdot \mathrm{kg}^{-1} \cdot \mathrm{hr}^{-1}$ in 58 of the 64 patient days (90\%).

There was an increase in dose requirement over time. In the 14 patients that received rocuronium infusions for at least three days, the infusion requirements averaged $0.65 \mathrm{mg} \cdot \mathrm{kg}^{-1} \cdot \mathrm{hr}^{-1}$ on day 1 and $0.84 \mathrm{mg} \cdot \mathrm{kg}^{-1} \cdot \mathrm{hr}^{-1}$ on day $3(P=0.07)$. In the five patients that received rocuronium for at least five days, the infusion requirements increased from $0.67 \mathrm{mg} \cdot \mathrm{kg}^{-1} \cdot \mathrm{hr}^{-1}$ on day 1 to 1.2 $\mathrm{mg} \cdot \mathrm{kg}^{-1} \cdot \mathrm{hr}^{-1}$ on day $5(P<0.05)$.

No problems with the ability to titrate the infusion or level of neuromuscular blockade were noted in any of the patients. The number of dose adjustments per day varied from 0 to 4 (median $=2$ ). When the rocuronium infusion was discontinued, spontaneous return of neuromuscular function (assessed by return of the TOF and sustained tetanus to a $50 \mathrm{~Hz}$ stimulus) was noted in 24 to $44 \mathrm{~min}(31 \pm 12 \mathrm{~min})$. No episodes of prolonged paralysis were noted.

\section{Discussion}

We have prospectively evaluated the dose requirements and the efficacy of using rocuronium by continuous infusion to provide neuromuscular blockade in the paediatric ICU patient. A wide variability in dose requirement was noted in the 20 patients. The infusion requirements varied from 0.3 to $2.2 \mathrm{mg} \cdot \mathrm{kg}^{-1} \cdot \mathrm{hr}^{-1}$ when considering all patients and patient days. The highest
TABLE Cardiovascular effects of rocuronium bolus in 14 patients

\begin{tabular}{llll}
\hline & Heart rate & Systolic BP & Diastolic BP \\
\hline Baseline & $121 \pm 31$ & $104 \pm 28$ & $62 \pm 28$ \\
Maximum & $132 \pm 42^{*}$ & $112 \pm 41 \dagger$ & $68 \pm 36 \dagger$ \\
\hline
\end{tabular}

$* P<0.05$ compared with baseline.

$\dagger P<0.01$ compared with baseline.

infusion rates were noted in patients that received the agent for prolonged periods of time. The requirements on day 1 were not as variable ranging from 0.3 to 0.8 $\mathrm{mg} \cdot \mathrm{kg}^{-1} \cdot \mathrm{hr}^{-1}$. However, the wide variability in requirements and changes in requirements over time further support the routine monitoring of neuromuscular function when these agents are used in the ICU patient. Similar variability in infusion requirements have been previously reported with both vecuronium ${ }^{7}$ and pancuronium. ${ }^{8}$

There are no previous reports evaluating the dose requirements of rocuronium in the paediatric ICU patient. Sparr et al. evaluated dose requirements during intravenous anaesthesia (propofol, alfentanil) and noted infusion requirements varying from 0.437 to $0.870 \mathrm{mg} \cdot \mathrm{kg}^{-1} \cdot \mathrm{hr}^{-1}$ (mean $\pm \mathrm{SD}=0.595 \pm 0.146$ $\left.\mathrm{mg} \cdot \mathrm{kg}^{-1} \cdot \mathrm{hr}^{-1}\right),{ }^{9}$ a range that is comparable with that of the present study. The wider variation in infusion rates of the current study may be explained by the different anaesthetic agents used (benzodiazepines in our patients versus propofol in the study of Sparr et al.) or the diversity of the patient population in the current study versus the relatively healthy surgical outpatient who is not receiving other drugs which may alter neuromuscular function.

There was an eight-fold variability in infusion requirement which is most likely the result of variations in patient age, underlying medical problems, concomitant medication administration, and underlying hepatic/ renal function. Due to the limited number of patients in each group, no comment can be made concerning the effects of these factors on rocuronium infusion requirement in the paediatric ICU patient.

The highest infusion rates in our population occurred in patients that were receiving rocuronium for five days or more. Although there was an increase in requirement noted each day, this did not reach statistical significance until day 5. Previous studies with other agents have noted similar increases in infusion requirement over time. ${ }^{10,11}$ In these previous studies, the recovery times for the return of normal neuromuscular function were normal despite the increasing dose requirement. Laboratory studies have demonstrated a mechanism for the increased dose requirements. Hogue et al. ${ }^{12}$ demonstrated extrajunctional receptors in rats that received 
chronic doses of d-tubocurarine and suggested that prolonged blockade, like denervation injury, leads to the proliferation of acetylcholine receptors. The upregulation of receptor density would explain the development of tachyphylaxis.

One concern with NMBAs is their effect on cardiovascular function. Vecuronium is generally used in the ICU patient because of its lack of adverse haemodynamic effects. Like vecuronium, we noted little haemodynamic change with rocuronium. Statistically significant, although clinically insignificant, increases in heart rate and blood pressure were noted following bolus administration. These were attributed to the mild vagolytic activity of rocuronium.

Our study population did not include patients with alterations of hepatic or renal function. Like vecuronium, rocuronium undergoes primarily hepatic metabolism. With vecuronium, prolonged activity is seen, especially after repeated doses, in patients with renal failure due to the accumulation of active hepatic metabolites including 3-desacetyl, 17-desacetyl, and 3,17 desacetyl. vecuronium. ${ }^{13}$ To date, active metabolites have not been identified following rocuronium administration. However, a prolonged effect may occur with either hepatic or renal dysfunction. Magorian et al. demonstrated a prolonged elimination half-life of rocuronium with an increased volume of distribution in patients with hepatic dysfunction. ${ }^{14}$ There are conflicting reports in patients with renal dysfunction. ${ }^{15,16}$ Cooper et al. demonstrated prolonged recovery and decreased clearance following a single bolus dose of rocuronium in adult patients with renal dysfunction. ${ }^{15}$ However, a subsequent study by Khuenl-Brady et al. did not detect any change in onset, duration of effect, or recovery in patients with renal failure. ${ }^{16}$ Further studies are needed to define these effects especially following repeated administration or prolonged infusions in the ICU population.

In summary, rocuronium can be administered by continuous infusion to provide neuromuscular blockade in the paediatric ICU patient. While the majority of patients required 0.3 to $1.0 \mathrm{mg} \cdot \mathrm{kg}^{-1} \cdot \mathrm{hr}^{-1}$, there was variability in dose requirements ranging from a minimum of 0.3 to a maximum of $2.2 \mathrm{mg} \cdot \mathrm{kg}^{-1} \cdot \mathrm{hr}^{-1}$. Several factors may account for the variability of infusion requirements in the ICU patient. Regardless of the mechanisms responsible for the variability, it further emphasizes the need for monitoring of neuromuscular function whenever these NMBAs are administered.

\section{References}

1 Klessig HT, Geiger HJ, Murray MJ, Coursin DB. A national survey on the practice patterns of anesthesiologist intensivists in the use of muscle relaxants. Crit Care Med 1992; 20: 1341-5.

2 Topulos GP. Neuromuscular blockade in adult intensive care. New Horiz 1993; 1: 447-62.

3 Mirakhur RK, Cooper AR, Clarke RSJ. Onset and intubating conditions of rocuronium bromide compared to those of suxamethonium. Eur J Anaesthesiol 1994; 11(Suppl 9): 41-3.

4 Tryba M, Zorn A, Thole H, Zenz M. Rapid-sequence orotracheal intubation with rocuronium: a randomized doubleblind comparison with suxamethonium-preliminary communication. Eur J Anaesthesiol 1994; 11(Suppl 9): 44-8.

5 Levy JH, Davis GK, Duggan J, Szlam F. Determination of the hemodynamics and histamine release of rocuronium (Org 9426) when administered in increased doses under $\mathrm{N}_{2} \mathrm{O} / \mathrm{O}_{2}$-sufentanil anesthesia. Anesth Analg 1994; 78 : 318-21.

6 Nitschmann P, Oberkogler.W, Hertsig M, Schwarz S. Comparison of haemodynamic effects of rocuronium bromide with those of vecuronium in patients undergoing CABG surgery. Eur J Anaesthesiol 1994; 11(Suppl 9): 113-5.

7 Eldadah MK, Newth CJL. Vecuronium by continuous infusion for neuromuscular blockade in infants and children. Crit Care Med 1989; 17: 989-92.

8 Tobias JD, Lynch A, McDuffee A, Garrett JS. Pancuronium infusion for neuromuscular block in children in the Pediatric Intensive Care Unit. Anesth Analg 1995; 81: $13-6$.

9 Sparr HJ, Khuenl-Brady KS, Erikson LI. Pharmacodynamics and pharmacokinetics of rocuronium following continuous infusion in patients during intravenous anaesthesia. Eur J Anaesthesiol 1994; 11(Suppl 9): 63-5.

10 Coursin DB, Klasek $G$, Goelzer $S L$. Increased requirements for continuously infused vecuronium in critically ill patients. Anesth Analg 1989; 69: 518-21.

11 Kushimo OT, Darowski MJ, Morris P, Hollis S, Meakin G. Dose requirements of atracurium in paediatric intensive care patients. Br J Anaesth 1991; 67: 781-83.

12 Hogue CWJr, Ward JM, Itani MS, Martyn JAJ. Tolerance and upregulation of acetylcholine receptors follow chronic infusions of $d$-tubocurarine. J Appl Physiol 1992; 72: 1326-31.

13 Segredo V, Caldwell JE, Matthay MA, Sharma $M L$, Gruenke $L D$, Miller RD. Persistent paralysis in critically ill patients after long-term administration of vecuronium. N Engl J Med 1992; 327: 524-8.

14 Magorian T, Wood P, Caldwell J, et al. The pharmacokinetics and neuromuscular effects of rocuronium bromide in patients with liver disease. Anesth Analg 1995; 80: 754-9.

15 Cooper RA, Maddineni VR, Mirakhur RK, Wierda JMKH, Brady M, Fitzpatrick KTJ. Time course of neuromuscular 
effects and pharmacokinetics of rocuronium bromide (Org 9426) during isoflurane anaesthesia in patients with and without renal failure. $\mathrm{Br} \mathrm{J}$ Anaesth 1993; 71: 222-6.

16 Khuenl-Brady KS, Pomaroli A, Pühringer F, Mitterschiffthaler $G$, Koller $J$. The use of rocuronium (ORG 9426 ) in patients with chronic renal failure. Anaesthesia 1993; 48: 873-5. 